\title{
Micro and Nanostructure Surface and Interface Characterization of Anodized Zr in Two Different Electrolytes
}

\author{
Andrei Bogdan Stoian, ${ }^{1}$ Maria Vardaki ${ }^{1}$ and Ioana Demetrescu ${ }^{1,2 \star}$ \\ ${ }^{1}$ Faculty of Applied Chemistry and Materials Science, Department of General Chemistry, University Politehnica of Bucharest, \\ 1-7 Gheorghe Polizu str., 011061, Bucharest, Romania \\ ${ }^{2}$ Academy of Romanian Scientists, 54 Spaiul Independentei, 050094, Bucharest, Romania \\ *Corresponding author: E-mail: ioana_demetrescu@yahoo.com; i_demetrescu@chim.upb.ro \\ Tel. +4 0214023930
}

Received: 03-13-2019

\begin{abstract}
The present work reports on the morphologies and properties of anodized $\mathrm{Zr}$ in two different electrolytes. The $\mathrm{Zr}$ phosphates $(\alpha-\mathrm{ZP})$ obtained in the inorganic electrolyte containing $\mathrm{H}_{3} \mathrm{PO}_{4}+\mathrm{NaF}$ and zirconia $\left(\mathrm{ZrO}_{2}\right)$ nanostructures formed in the organic glycerol-based electrolyte were investigated by SEM, FT-IR and AFM. The surface analysis was completed by contact angles measurements. It was found that the type of electrolyte along with the applied voltage influence the structure of the sample and being more precise, the anodic oxidation in $\mathrm{H}_{3} \mathrm{PO}_{4}$ electrolyte promotes the evolution of flaky structures and eventually of pores by increasing the applied voltage, while the anodizing performed in glycerol-based electrolyte results in the formation of nanoporous structures that evolve into nanotubes as the applied voltage grows. Based on experimental data a film forming mechanism for $\alpha-\mathrm{ZP}$ and $\mathrm{ZrO}_{2}$ was proposed and correlated to analyzed surface properties.
\end{abstract}

Keywords: Zirconium phosphate; zirconia; anodizing; organic; inorganic; electrolyte

\section{Introduction}

Due to its remarkable physical, chemical and mechanical properties, zirconium $(\mathrm{Zr})$ has been used in various fields including nuclear industry for having low neutron absorption and microelectronic industry for having high dielectric constant. ${ }^{1,2} \mathrm{Zr}$ is a strong, reactive valve metal that possesses physical and chemical properties similar to titanium (Ti) forming spontaneously a protective oxide film when it comes in contact with air. With a passive film, $\mathrm{Zr}$ presents an excellent resistance to corrosion in a variety of conditions, such as organic solutions, alkalis and acids and can be considered a promising and useful material that can be used in applications such as oxygen sensors, ${ }^{3}$ protective coating materials in optical devices, ${ }^{4}$ photocatalysts in environmental applications ${ }^{5}$ and catalysts for fuel cells. ${ }^{6}$ It is to mention that $\mathrm{Zr}$ is considered one of the most biocompatible elementsand a good choice for restorative works in oral cavity, ${ }^{7-9}$ being a competition for Ti and Ti alloys. ${ }^{10,11}$ Oral cavity environ- ments are very aggressive not only because of saliva, but for their varying $\mathrm{pH}$ content as well, and the excellent resistance to corrosion of $\mathrm{Zr}$ and $\mathrm{Zr}$ alloys especially in combination with $\mathrm{Ti}$ is a strong point for recommendation as biomaterial. ${ }^{12-14}$ The present work reports on formation of zirconium phosphates $(\alpha-\mathrm{ZP})$ as a result of anodizing in inorganic $\mathrm{H}_{3} \mathrm{PO}_{4}+\mathrm{NaF}$ electrolyte. It is important to know that $a-Z P$ materials ${ }^{15}$ thanks to their properties (thermal stability, ion exchange capability, good biological compatibility etc.) can be considered good candidates for a variety of applications, like for example to be used in catalysis ${ }^{16}$ and photochemistry. ${ }^{17}$ The ease of formation and modification along with the excellent properties makes $\alpha-\mathrm{ZP}$ an urgent topic of ongoing research aiming to the extension of their applications in various fields, ${ }^{18,19}$ being considered an old material with a bright future. Regarding the anodizing of $\mathrm{Zr}$ in the organic electrolyte, $\mathrm{ZrO}_{2}$ nanostructures formed present desired qualities that proved to be useful for many applications, including biomedical field. ${ }^{20}$ Further, it was found 
that the way of self-organization of obtained $\mathrm{ZrO}_{2}$ nanotubes appears to be very much alike to that proposed for $\mathrm{Ti}^{21,22} \mathrm{Zr}$ anodic oxidation via electrochemical anodizing is a facile and inexpensive method for surface modification, providing the opportunity for obtaining a variety of different nanostructures based on the applied conditions (electrolyte, $\mathrm{pH}$, applied voltage, post treatments etc.). In the present work is reported the fabrication of $\alpha-\mathrm{ZP}$ and $\mathrm{ZrO}_{2}$ nanostructures and shows how the used electrolyte and the applied electrochemical conditions during the anodizing process can affect the final structure, morphology and properties of the samples. Based on experimental data, a film forming mechanism for $\alpha-\mathrm{ZP}$ and $\mathrm{ZrO}_{2}$ was proposed and, as novelty, was direct correlated to analyzed surface properties.

\section{Experimental}

Zr samples (foil, thickness $0.1 \mathrm{~mm}, 99.98 \%$ - Sigma-Aldrich) were cleaned in an ultrasonic bath in distilled water and ethanol for 10 minutes each. The samples were then dried in atmosphere at room temperature. The surface modification was achieved by anodizing the samples with a Matrix MPS-7163 DC power supply. The anodizing was carried out for 60 minutes applying different voltages for each sample $(5 \mathrm{~V}, 15 \mathrm{~V}, 45 \mathrm{~V}$ and $75 \mathrm{~V})$ using the $\mathrm{Zr}$ sample as the anode and $\mathrm{Pt}$ foil as the cathode. Two sets of samples were produced by using different electrolytes. The first electrolyte (E1) containing $2 \mathrm{M} \mathrm{H}_{3} \mathrm{PO}_{4}(85$ wt.\% - Sigma-Aldrich) and $30 \mathrm{mM} \mathrm{NaF} \mathrm{(>98 \%} \mathrm{-} \mathrm{Sig-}$ ma-Aldrich) was used to obtain $\mathrm{Zr}$ phosphates and the second electrolyte (E2) containing glycerol $15 \mathrm{vol} \% \mathrm{H}_{2} \mathrm{O}+$ $0.2 \mathrm{M} \mathrm{NH}_{4} \mathrm{~F}$ was used to obtain $\mathrm{ZrO}_{2}$ nanostructures. ${ }^{23}$ The micro surface morphologies of the $\mathrm{Zr}$ samples were investigated with a Quanta 650 scanning electron microscope (SEM) from FEI in high vacuum at $10 \mathrm{kV}$. The coating thickness was evaluated by scratching the film and measuring the cross section with the SEM. The infrared spectra (FT-IR) were obtained with a Perkin-Elmer Spec- trum 100 spectrometer in the range $4000-600 \mathrm{~cm}^{-1}$. Micro roughness and adhesion forces were evaluated using an A.P.E. Research A100-SGS atomic force microscope (AFM) from 5 measurements for each sample. The wettability of the samples was evaluated with a CAM100 equipment from KSV Instruments using ultra-pure water. The contact angle values represent the average of 5 measurements.

\section{Results and Discussion}

\section{1. Surface Morphology}

Fig. 1a shows the surface of $\mathrm{Zr}$ samples anodized in $\mathrm{E} 1$ at $5 \mathrm{~V}$ that are covered in two types of structures: the first type is represented by small semi-spheres with diameters of approximately $300 \mathrm{~nm}$ which form small clusters; the second type is represented by ridges with lengths of 1-3 $\mu \mathrm{m}$ and widths of 30 to $400 \mathrm{~nm}$. On the same sample there was observed a phenomenon of bubble formation (10-100 $\mu \mathrm{m}$ diameter) and breaking, with the result of superficial stratum exfoliation. Outside the sites of former bubbles, a higher concentration of $a-\mathrm{ZP}$ ridges was observed. This observed process of bubble forming and braking was not completed during the anodizing time and on the surface are present sites in all development stages. Anodizing in E2 at the same voltage (Fig. 1b) led to the formation on the surface of the samples of an oxide layer with the thickness ranging between $200-400 \mathrm{~nm}$. The oxide formation is the result of following reactions presented below ${ }^{7}$ :

$$
\begin{aligned}
& \mathrm{Zr}+2 \mathrm{H}_{2} \mathrm{O} \rightarrow \mathrm{ZrO}_{2}+4 \mathrm{H}^{+}+4 \mathrm{e}^{-} \\
& \mathrm{ZrO}_{2}+4 \mathrm{H}^{+}+6 \mathrm{~F}^{-} \rightarrow\left[\mathrm{ZrF}_{6}\right]^{2-}+2 \mathrm{H}_{2} \mathrm{O}
\end{aligned}
$$

The role of fluoride ions in the oxide formation and in its stability has been reported in literature. $\mathrm{ZrO}_{2}$ nanostructures formation in $\mathrm{F}^{-}$containing electrolytes is the result of the competition between the electrochemical oxide formation and the chemical dissolution of said oxide

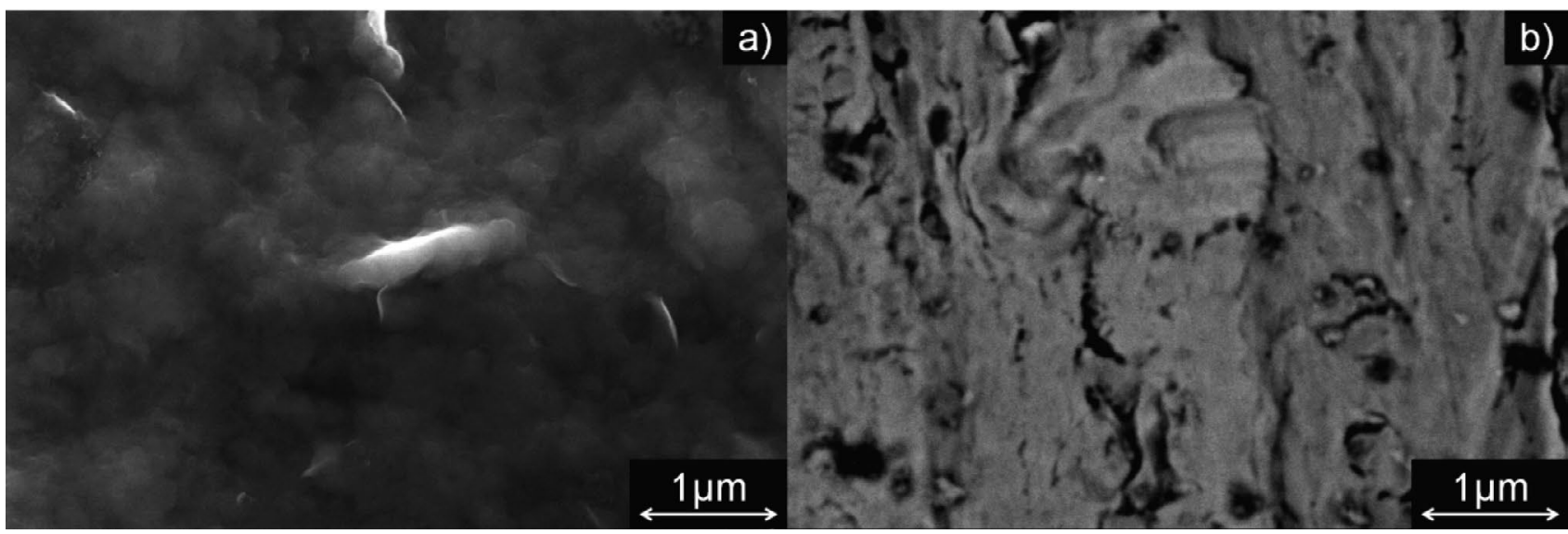

Fig. 1 SEM micrographies for Zr samples anodized at $5 \mathrm{~V}$ in a) E1; b) E2 


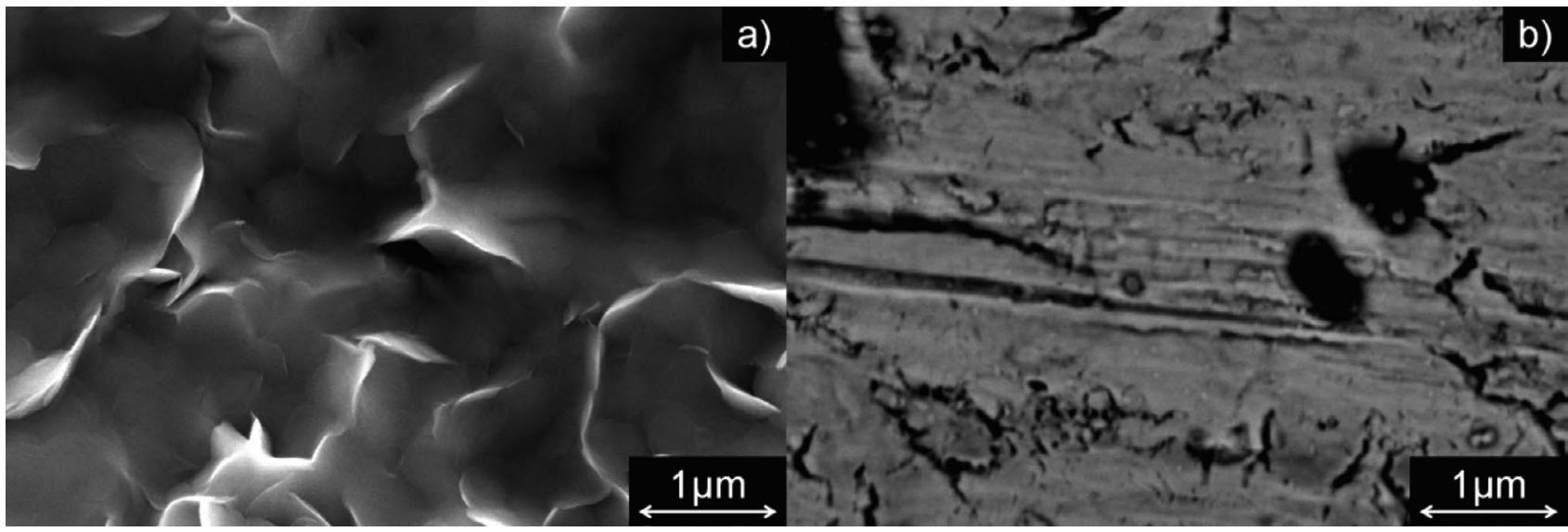

Fig. 2 SEM micrographies for $\mathrm{Zr}$ samples anodized at $15 \mathrm{~V}$ in a) E1; b) E2

through an intermediate stage where complex hexafluorozirconate anions form.

This oxide layer is covered in random cracks and incipient pores with diameters of around $100 \mathrm{~nm}$ start to appear.

At $15 \mathrm{~V}$, anodizing in $\mathrm{E} 1$ led to a seemingly homogeneous surface shown in Fig. 2a. The two types of structures: semi-spheres (250 $\mathrm{nm}$ diameter) and ridges (length $300-800 \mathrm{~nm}$ and $60-100 \mathrm{~nm}$ width) are still present. However, in this case, the higher voltage led to an increased process speed. As such, there are no remaining bubbles on the surface at the end of the anodizing process, although the sites are still observable. The bubbles, which formed on the surface, were smaller (around $10 \mu \mathrm{m}$ diameter) but denser. It is also evident that there are more $\alpha$-ZP structures formed and at this voltage, they begin to take their classical flaked, laminar and aggregated shapes. Electrolyte E2 produced at $15 \mathrm{~V}$ a surface similar to the one obtained at $5 \mathrm{~V}$ (Fig. 2b). The differences occur in the dimensions of the surface features. The oxide layer is similar in thickness,

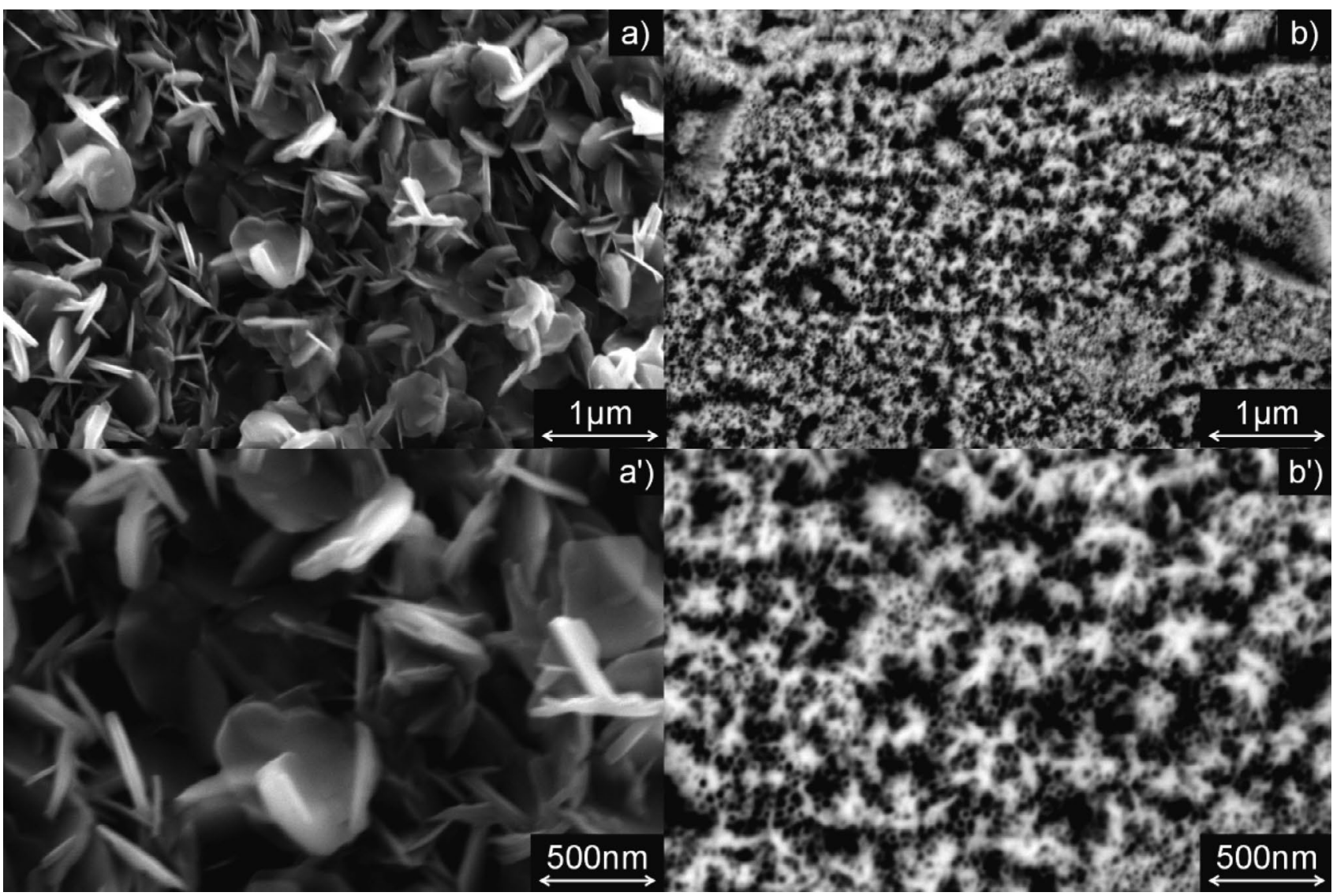

Fig. 3 SEM micrographies for $\mathrm{Zr}$ samples anodized at $45 \mathrm{~V}$ in a), a') E1; b), b') E2 
but the cracks are deeper, wider, more numerous and the now well-formed pores have diameters between $100 \mathrm{~nm}$ and $4 \mu \mathrm{m}$.

When the anodizing voltage was increased to $45 \mathrm{~V}$ the sample anodized in E1 was completely covered with a-ZP structures (Fig. 3 a, a').

These quasi-hexagonal pellet structures had lengths of around $600 \mathrm{~nm}$ and thicknesses of around $80 \mathrm{~nm}$ and were not ordered in any particular direction. Underneath this stratum, a porous $\mathrm{ZrO}_{2}$ surface was found present, with uniform pores having diameters of around $200 \mathrm{~nm}$. Anodizing in E2 led to the covering of the $\mathrm{Zr}$ sample with $\mathrm{ZrO}_{2}$ a mixture of nanopores, nanotubes and nanograss (Fig. 3 b, b'). Nanopores were observed on the thick initial oxide layer that hadn't dissolved totally at this voltage. The nanograss was found at the remaining boundary between the nanopore and nanotube layers and is probably a byproduct of partial dissolution of the top porous layer. The nanotubes diameters range between 20 and $50 \mathrm{~nm}$ and the wall thickness is around $10 \mathrm{~nm}$. Their length varies and are not particularly well organized. The tops of some of the nanotubes are covered and merge to form the nanograss.

At the highest studied anodizing voltage of $75 \mathrm{~V}$, on the surface of the sample fabricated in E1 there are visible both $a-\mathrm{ZP}$ structures and a $\mathrm{ZrO}_{2}$ surface covered with pores (Fig. 4a, a').
The $\alpha$-ZP structures are found in laminated aggregates formed by multiple pellets and have sizes from 0.17 to $1 \mu \mathrm{m}$ in length and 24 to $123 \mathrm{~nm}$ in thickness. The $\mathrm{ZrO}_{2}$ pores present on the surface have diameters of around 400 $\mathrm{nm}$. Anodizing in E2 led to the formation of two surfaces covered in nanotubes (Fig. 4b, b'). The first surfaces is represented by the initial oxide layer that partially dissolved which is now covered with closely packed nanotubes with diameters around $28 \mathrm{~nm}$ and wall thicknesses around 10 $\mathrm{nm}$. The second surface positioned just beneath the first is represented by new oxide formed and dissolved during the anodization process at equilibrium. This surface is covered with larger and better organized nanotubes with diameters of around $75 \mathrm{~nm}$ and wall thicknesses around $14 \mathrm{~nm}$.

\section{2. FT-IR Analysis}

The corresponding FT-IR spectra of the obtained samples are shown in Fig.5. For the sample anodized in E1, the spectra ${ }^{23}$ exhibit the characteristics vibration bands from the phosphate group (Fig. 5a). The broad band around $3150 \mathrm{~cm}^{-1}$ attributed to $\mathrm{OH}$ stretching of water molecules and the weak peak at around $1620 \mathrm{~cm}^{-1}$ indicates the bending of the water molecules. More water seems to be present on samples obtained at lower voltages. The strong band centered around $960 \mathrm{~cm}^{-1}$ corresponds to

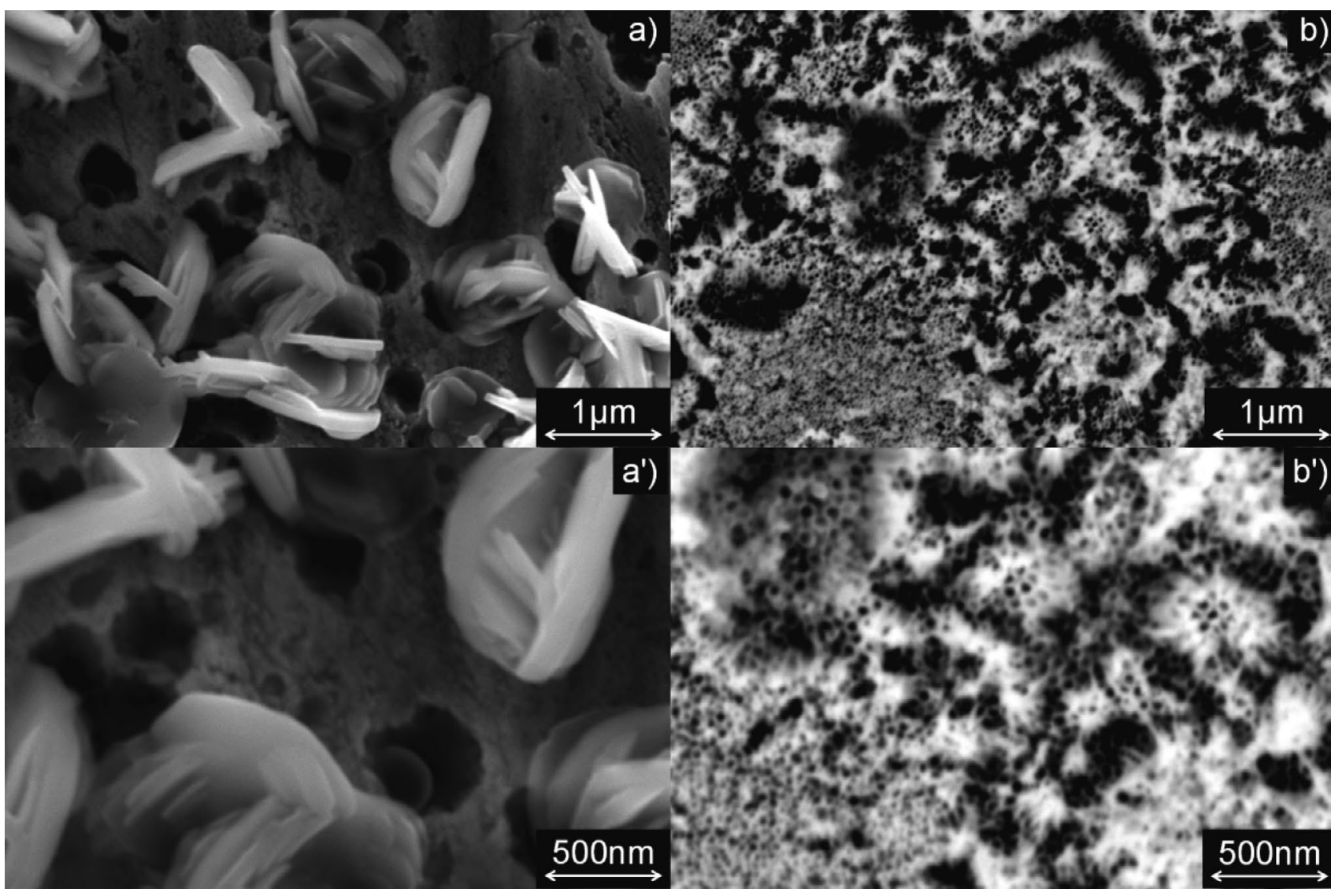

Fig.4 SEM micrographies for Zr samples anodized at $75 \mathrm{~V}$ in a), a') E1; b), b') E2 


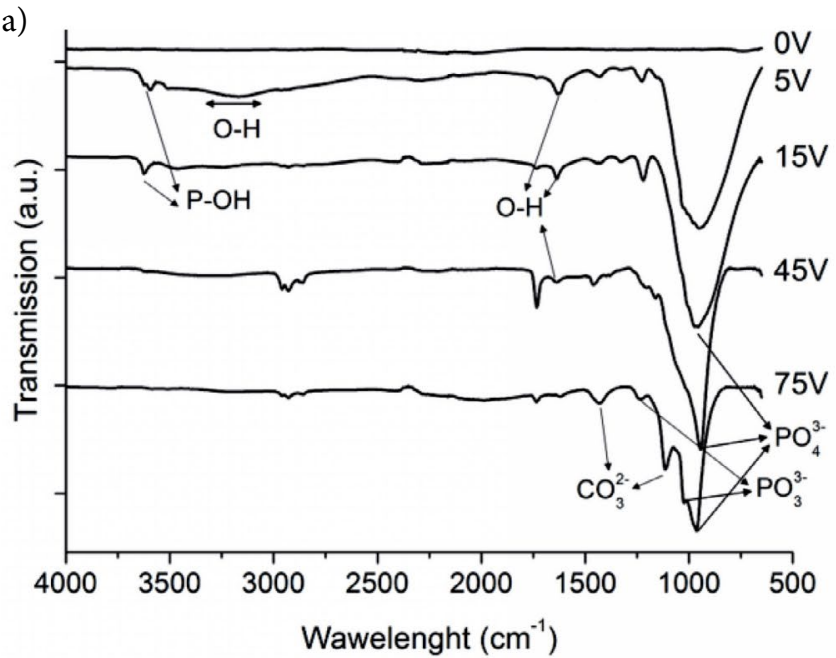

Fig. 5 FT-IR spectra for Zr samples covered with a) phosphates; b) oxides

some distorted tetrahedral phosphate groups in the nuclei of zirconium phosphates. The band at $1126 \mathrm{~cm}^{-1}$ corresponds to the deformation vibrations of $\mathrm{P}-\mathrm{O}$ bonding of the $\mathrm{PO}_{3}$ terminal groups. This band is only visible at the sample obtained at $75 \mathrm{~V}$. Two bands at 3660 and $3643 \mathrm{~cm}^{-1}$ are due to free and hydrogen bonded surface $\mathrm{P}-\mathrm{OH}$ groups respectively and are more evident for samples obtained at $5 \mathrm{~V}$ and $15 \mathrm{~V}$. In the region of phosphate vibrations spectra of all samples exhibits bands at 1445, 1425, 1369, 1350 and $1208 \mathrm{~cm}^{-1}$. These bands were observed in the FT-IR spectra of $a-Z P$. The two weak, bands at 1445 and $1425 \mathrm{~cm}^{-1}$ may be due to impurities of surface carbonate. The peaks attributed to phosphates become more well defined with the increase of the elaboration voltage.

The spectra anodized in E2 (Fig. 5b) show characteristic bands for $\mathrm{ZrO}_{2}$ covered surfaces. The band around $3900-3600 \mathrm{~cm}^{-1}$ is characteristic for $\mathrm{H}_{2} \mathrm{O}$. The broad band around $3150 \mathrm{~cm}^{-1}$ attributed to $\mathrm{OH}$ stretching of water molecules and the weak peak at around $1620 \mathrm{~cm}^{-1}$ that indicates the bending of the water molecules is present on $\mathrm{ZrO}_{2}$ samples as well. At around $2400-2200 \mathrm{~cm}^{-1}$ all samples show residues of $\mathrm{CO}_{2}$. The absorbtion peaks of $\mathrm{Zr}-\mathrm{O}$ vibrational bond are present for all the samples and the signal was found to be increasing with the anodizing voltage.

\section{3. Contact Angle Measurements}

Contact angle measurements (Table 1) show that polished $\mathrm{Zr}$ is slightly hydrophillic. Samples covered with $\alpha$-ZP show a constant decrease of contact angle values with the increase of the anodizing voltage. $\mathrm{ZrO}_{2}$ samples show an increase of contact angle values at $5 \mathrm{~V}$, reaching the limit of hydrophobicity, however, as the anodizing voltage increases, the contact angle values rapidly drop, reaching a state of super hydrophillicity at $75 \mathrm{~V}$.

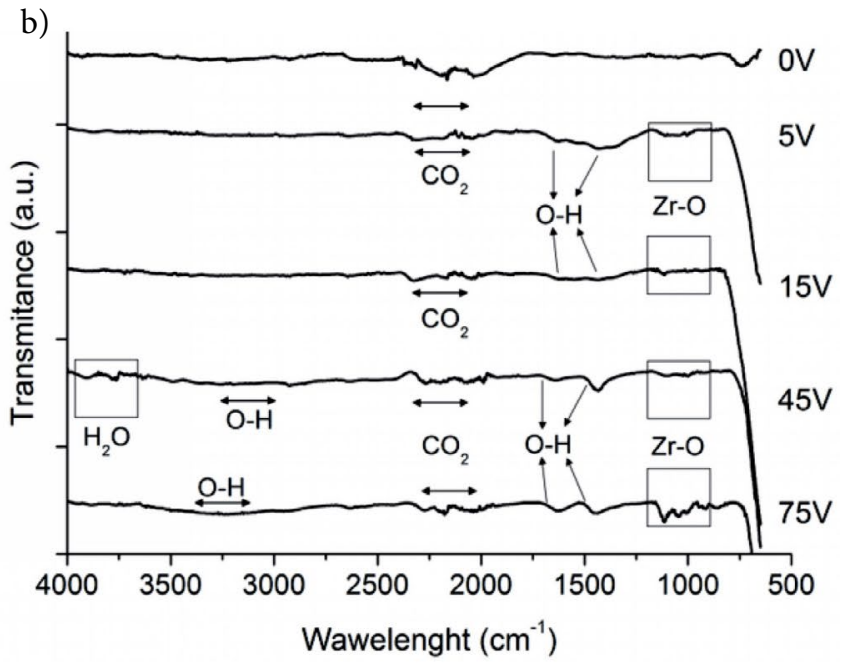

Table 1 Average contact angle values for Zr samples.

\begin{tabular}{llr}
\hline $\begin{array}{l}\text { Applied voltage } \\
(\mathrm{V})\end{array}$ & \multicolumn{2}{c}{ Contact angle $\left(^{\circ}\right)$} \\
\hline 0 & $69.1 \pm 3.4$ & \multicolumn{1}{c}{$\mathbf{Z r O}_{\mathbf{2}}$} \\
\hline 5 & $35.5 \pm 2$ & $69.1 \pm 3.4$ \\
15 & $32.4 \pm 1.8$ & $91 \pm 4.1$ \\
45 & $31.6 \pm 1.4$ & $27.3 \pm 2.1$ \\
75 & $26.1 \pm 1.2$ & $16 \pm 1.2$ \\
\hline
\end{tabular}

\section{4. AFM Analysis}

The roughness values $(\mathrm{Ra})$ for the samples obtained in the two electrolytes are shown in Table 2.

Table 2 Average roughness values for $\mathrm{Zr}$ samples.

\begin{tabular}{lcl}
\hline $\begin{array}{l}\text { Applied voltage } \\
(\mathbf{V})\end{array}$ & $\mathbf{a - Z P}$ & $\mathbf{R a}(\mathbf{n m})$ \\
\hline 0 & $36 \pm 4$ & $\mathbf{Z r O}_{\mathbf{2}}$ \\
5 & $358 \pm 16.9$ & $36 \pm 4$ \\
15 & $178 \pm 9.2$ & $85 \pm 5.5$ \\
45 & $127 \pm 8.1$ & $36 \pm 2.6$ \\
75 & $154 \pm 8.7$ & $40 \pm 3.1$ \\
\hline
\end{tabular}

As can be noticed, the values for the roughness of the samples covered with $\alpha$-ZP structures are around 4 times higher than those obtained for the samples covered with $\mathrm{ZrO}_{2}$ nanotubes. However, the trend is similar, both types of samples experiencing an increase of roughness at $5 \mathrm{~V}$, followed by a steady decrease as the voltage rises. This phenomenon can be attributed to the balance between phosphate/oxide formation and dissolution on and from the 

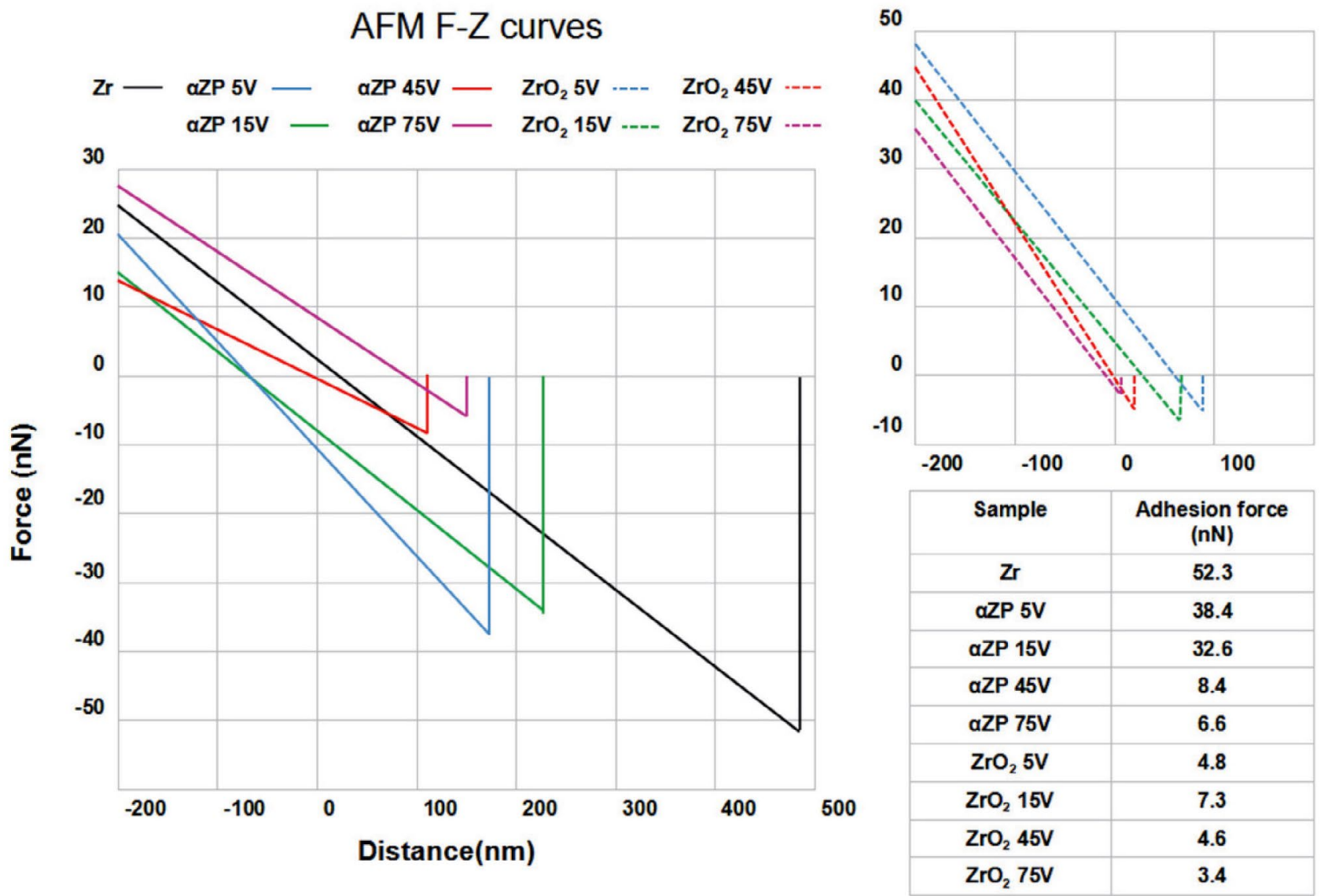

Fig. 6 Normalized median values for AFM tip adhesion forces (F-Z curves)

samples surfaces during anodizing that is dependent on the applied voltage.

The normalized median values for the adhesion force measured with the AFM are shown as F- $Z$ diagrams in Fig. 6. Polished $\mathrm{Zr}$ has the highest adhesion force, probably given by the smooth surface. This force is also active a great distance from the surface, the AFM tip being affected at around $480 \mathrm{~nm}$ from the surface. Samples covered with $\alpha-Z P$ structures have smaller attraction forces than bare $\mathrm{Zr}$. The forces values and action range decrease steadily with the voltage.

The adhesion force measured by AFM experienced a decreasing trend with the increase of the sample elaboration voltage, suggesting the formed phosphate was the primary responsible for the reduction of the adhesion forces. Thin crystalline phosphates are produced on the $\mathrm{Zr}$ surface, the phosphate coating reducing the frictional force produced through shaping, drawing or slip processes $\mathrm{ZrO}_{2}$ samples have the smallest forces that act only close to the surface. The capillaries on the surface provide better absorbent qualities, yielding different general surface qualities. The system formed by the SiC AFM tip and the surface of the samples experiences repulsive interactions mostly because of hydration forces which generate a decrease in friction coefficients and adhesion forces. The two surfaces seem to have different hardness levels, $\mathrm{ZrO}_{2}$ surfaces producing higher displacements of the AFM tip than $\alpha-Z P$ surfaces at the maximum indentation depth.

Fig. 7 shows the probable film forming mechanism for $\alpha-\mathrm{ZP}$ and $\mathrm{ZrO}_{2}$ structures covered surfaces. From the gathered data, we deduced that competing phenomena are occurring on the surface during the anodizing process in both cases. These processes are: forming of $\mathrm{Zr}$ phosphates and/or oxides (depending on the electrolyte), dissolution of $\mathrm{ZrF}_{6}{ }^{2-}$ complexes from the surface and forming of auto-organized zirconium compound structures. Regardless of the used electrolyte, these phenomena are influenced by the anodizing voltage which changes the balance and the speeds at which these phenomena occur, leading to different results. As was largely described in the literature, ${ }^{22}$ anodizing parameters such as time, voltage, temperature and most important anodizing electrolyte composition are critical for the resulting desired morphologies. The composition of the sample surface seems to be less affected by the anodizing potential, instead being directly affected by the electrolyte composition. 


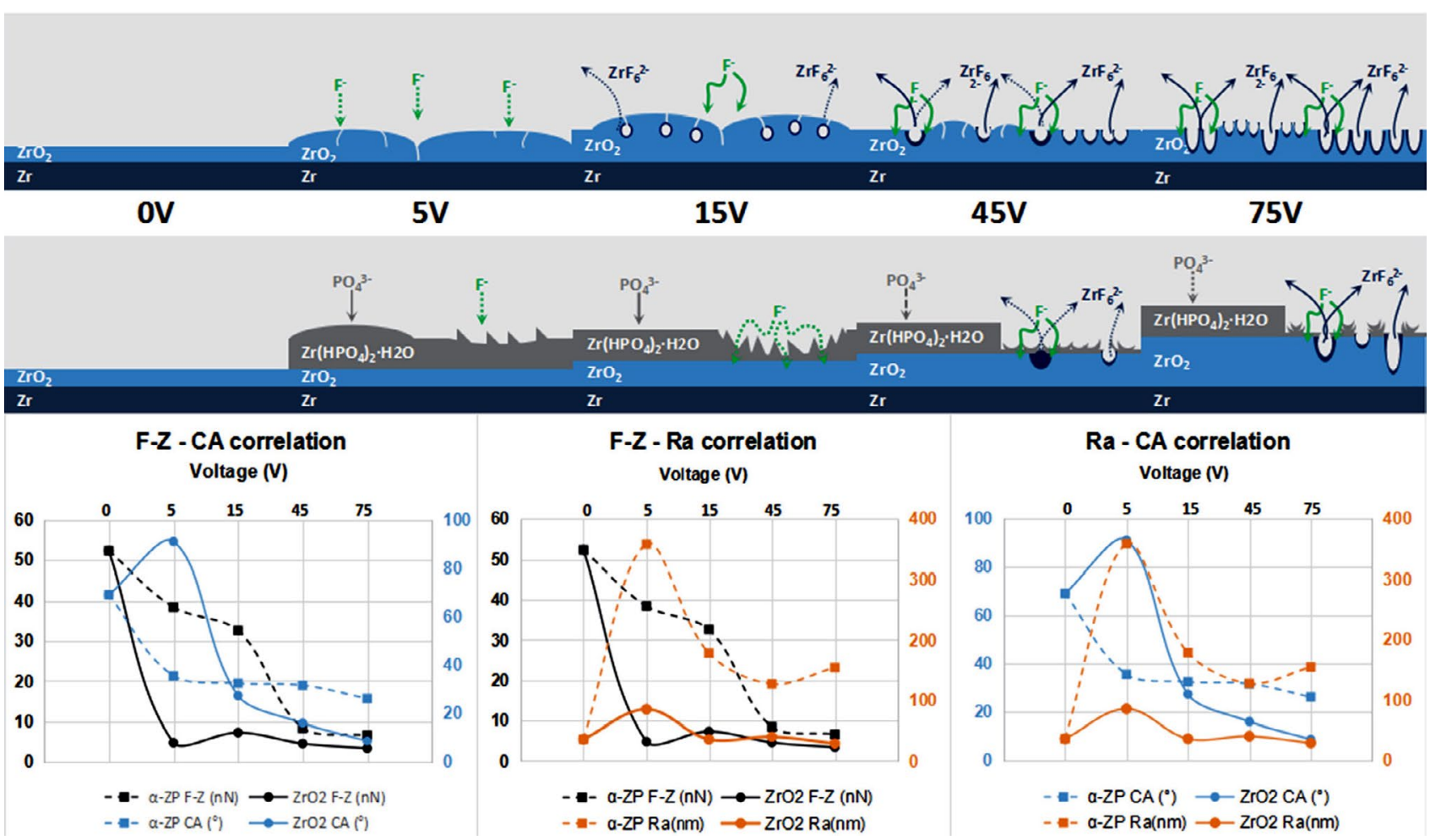

Fig. 7 Proposed film forming mechanism for $\alpha-\mathrm{ZP}$ and $\mathrm{ZrO}_{2}$ and correlation of analyzed surface properties

\section{Conclusions}

The SEM and AFM investigations revealed that structures with various sizes and shapes can be obtained by modifying the anodizing both the voltage and the electrolyte. On the surface of $\mathrm{Zr}$ anodized in $\mathrm{H}_{3} \mathrm{PO}_{4}$ a-ZP flake structures were obtained. These structures became more organized with the increase of the voltage and, at higher voltages, $\mathrm{ZrO}_{2}$ pores began to form. When glycerol used, the formation of auto-organized nanotubes was found to be directly dependent on the applied voltage. The roughness is influenced by the type as well as by the degree of homogeneity of structures formed on the surfaces. The wettability and the AFM micro adhesion forces and roughness values can be correlated to some degree for both samples. In the case of orthopedic and dental implants it is usually reported that hydrophillic materials have higher biocompatibility, facilitating initial interaction between the biomaterial and the biofluids, thus promoting osseointegration. Roughness has a major role in the wettability of a biomaterial as well in the subsequent cell interaction with the implant surface. Based on all experimental data, a film forming mechanism for $\alpha-\mathrm{ZP}$ and $\mathrm{ZrO}_{2}$ was proposed and correlated to analyzed surface properties. From a physical concept, these results enable the understanding of the optimal properties needed for the development of damage-tolerant thin films leading to practical applications.

\section{Acknowledgments}

This work was supported by the Romanian Government National Council of Scientific Research in Higher Education (CNCSIS) - Executive Unit for Financing Higher Education, Research, Development and Innovation (UEFISCDI), project number PN-III-P4-ID PCE 2016-0316.

\section{References}

1. B. Cox, J. Nucl. Mater. 2005, 336, 331-368.

2. A. Gomez-Sanchez, M. Katunar, W. Schreiner, G. Duffó, S. Ceré, D. J. Schiffrin, Acta Chim. Slov. 2014, 61, 316-327. DOI:10.1016/j.jnucmat.2004.09.029

3. E. Ivers-Tiffee, K. H. Hardtl, W. Menesklou, J. Riegel, Electrochim. Acta 2001, 47, 807-814.

DOI:10.1016/S0013-4686(01)00761-7

4. Q. Zhang, J. Shen, Wang, G. Wu, L. Chen, Int. J. Inorg. Mater. 2000, 2, 319-323. DOI:10.1016/S1466-6049(00)00037-4

5. A. I. Ahmed, S. A. El-Hakam, S. E. Samra, A. A. El-Khouly, A. S. Khder, Colloids Surf. A Physicochem. Eng. Asp. 2008, 317, 62-70. DOI:10.1016/j.colsurfa.2007.09.043

6. H. J. Cho, G. M. Choi, J. Power Sources 2008, 176, 96-101. DOI:10.1016/j.jpowsour.2007.09.118

7. D. E. Romonti, A. Gomez Sanchez, I. Milosev, I. Demetrescu, S. Cere, Mater. Sci. Eng. C, 2016, 62, 458-466. 
DOI:10.1016/j.msec.2016.01.079

8. G. O. Buica, A. B. Stoian, D. Ionita, I. Demetrescu Mater. Corros. 2018, 69, 1713-1719. DOI:10.1002/maco.201810277

9. A. Gomez Sanchez, J. Ballarre, J. C. Orellano, G. Duffó, S. Cere, J. Mater. Sci. Mater. Med., 2013, 24, 161-169.

DOI:10.1007/s10856-012-4770-8

10. M.Mindroiu, E.Cicek, F. Miculescu, I. Demetrescu, Rev. Chim. Bucharest 2007, 58, 898-903.

11. I. Milošev, B. Kapun, V. S. Šelih, Acta Chim. Slov. 2013, 60, 543-555.

12. C. Vasilescu, S. I. Drob, P. Osiceanu, J. M. Calderon Moreno, M. Prodana, D. Ionita, I. Demetrescu, M. Marcu, I. A. Popovici, E. Vasilescu Metall and Mat. Trans. A, 2017, 48, 513-523. DOI:10.1007/s11661-016-3774-2

13. A. B. Stoian, M. Vardaki, D. Ionita, M. Enachescu, O. Brancoveanu, I. Demetrescu, Ceram. Int., 2018, 44, 7026-7033. DOI:10.1016/j.ceramint.2018.01.137

14. S. Minagar, C. C. Berndt, J. Wang, E. Ivanowa, C. Wen, Acta Biomater. 2012, 8, 2875-2888.

DOI:10.1016/j.actbio.2012.04.005

15. T. Hanawa, Y. Tsutsumi, Bioceram. Dev. Appl., 2010, 1, DOI:10.1007/s11661-016-3774-2
16. K. Segawa, S. Nakata, S. Asaoka, Mater. Chem. Phys. 1987, 17, 181-200. DOI:10.1016/0254-0584(87)90055-1

17. C. Kumar, A. Chaudhari, G. Rosenthal, J. Am. Chem. Soc. 1994, 116, 403-404. DOI:10.1021/ja00080a059

18. H. Xiao, S. Liu Mater. Des. 2018, 155, 19-35. DOI:10.1016/j.matdes.2018.05.041

19. M. Pica, A. Donnadio, M. Casciola, Coord. Chem. Rev. 2018, 374, 218-235. DOI:10.1016/j.ccr.2018.07.002

20. W. Jang, J. He, J. Zhong, J. Lu, S. Yuan, B. Liang, Appl. Surf. Sci., 2014, 307, 407-413. DOI:10.1016/j.apsusc.2014.04.047

21. K. Yasuda, J. M. Macak, S. Berger, A. Ghicov, P. Schmuki, J. Electrochem. Soc. 2007, 154, C472-C478.

DOI:10.1149/1.2749091

22. M. Kulkarni, A. Mazare, P. Schmuki, A. Iglic, Adv. Mater. Lett., 2016, 7, 23-28. DOI:10.5185/amlett.2016.6156

23. F. Muratore, A. Baron-Wiechéc, T. Hashimoto, A. Gholinia, P. Skeldon, G. E. Thompson, Electrochim. Acta, 2011, 56, 10500-10506. DOI:10.1016/j.electacta.2010.12.089

24. X.g He, H. Xiao, H. Choi, A. Díaz, B. Mosby, A. Clearfield, H. Liang, Colloids. Surf. A 2014, 452, 32-38.

DOI:10.1016/j.colsurfa.2014.03.041

\section{Povzetek}

Pričujoče delo obravnava morfologijo in lastnosti anodiziranega Zr v dveh različnih elektrolitih. Cirkonijev fosfat ( $\alpha$-ZP) smo pripravili v anorganskem elektrolitu, ki je vseboval $\mathrm{H}_{3} \mathrm{PO}_{4}$ in $\mathrm{NaF}$. Nano cirkonijev oksid $\left(\mathrm{ZrO}_{2}\right)$ smo pripravili v elektrolitu na osnovi glicerola. Spojini smo karakterizirali z naslednjimi metodami vrstično elektronsko mikroskopijo (SEM), infrardečo spektroskopijo (FT-IR) in mikroskopom na atomsko silo (AFM). Analizo površine smo preiskovali tudi z meritvami kontaktnih kotov. Ugotovili smo, da vrsta elektrolita skupaj z uporabljeno napetostjo vpliva na strukturo vzorca. Anodna oksidacija v elektrolitu $\mathrm{H}_{3} \mathrm{PO}_{4}$ pospešuje nastanek in razvoj luskastih struktur in sčasoma por $\mathrm{s}$ povečanjem uporabljene napetosti. Pri procesu anodne oksidacije v elektrolitu na osnovi glicerola pa nastajajo nanoporozne strukture, ki se pri naraščanju napetosti razvijajo v nanocevke. Na podlagi eksperimentalnih podatkov smo predlagali mehanizma za oblikovanje $\alpha-\mathrm{ZP}$ in $\mathrm{ZrO}_{2}$ v povezavi $\mathrm{z}$ analiziranimi lastnostmi površin.

Except when otherwise noted, articles in this journal are published under the terms and conditions of the Creative Commons Attribution 4.0 International License 